\title{
The Mystics of Andalusia: Ibn Barrajan and Islamic Thought in the Twelfth Century
}

\author{
Yousef Casewit
}

Cambridge: Cambrdige University Press, 2017. 353 pages.

The Mystics of al-Andalus by Yousef Casewit, assistant professor of Qur'anic studies at the University of Chicago Divinity School, tells the story of an overlooked mystical school of Andalusia, the Mu'tabirun (lit. "the contemplators" or "the practicers of $i$ 'tibā $r$ "). The Mu'tabirun, as Casewit demonstrates, formulated a mystical teaching centered on contemplating God's signs in creation and the Book, and that self-consciously distinguished itself from the Sufis of 
the East. This book details the ways in which Ibn Barrajan (d. 536/1141), Ibn al- 'Arif (d. 536/1141), and Ibn Qasi (d. 546/1151), the school's main authors, contributed to Andalusi mystical thought and provided a link between Ibn Masarra (d. 319/931) and Ibn al- 'Arabi (d. 637/1240).

This book comprises eight chapters. The first two frame Casewit's intervention into the historiography of Islamic spirituality in al-Andalus. Chapter 1, "The Beginnings of Mystical Discourse in al-Andalus," provides a concise history of mystical discourse and practices from the Umayyads to the end of the Murabitun (the seventh to the twelfth century). The major precursor of the Mu'tabirun was Ibn Masarra, whose Risālat al-I'tibār presents an intellectual-cum-spiritual practice of contemplating God's signs $(\bar{a} y \bar{a} t)$ in the book of nature in order to ascend the ladder of knowledge to divine unity. Controversially, Ibn Masarra maintained that $i$ 'tibār could lead to the same truths as revelation. In 961, thirty years after his death, his books were burned at the behest of the jurists and his followers were forced to publicly disavow their master. His teachings, however, continued clandestinely.

Chapter 2, "The Rise of the Andalusi Mu'tabirun," focuses on the Mu'tabirun and challenges long-standing scholarly views on these mystics. This is a pivotal chapter for Casewit's monograph, as it introduces Ibn Barrajan, Ibn al-'Arif, and Ibn Qasi as Mu'tabirun and problematizes using the label "Sufi" for their project. Casewit convincingly disentangles them from the supposed influence of Abu Hamid al-Ghazali, which has dominated literature on the Mu'tabirun. Likewise, he distinguishes between the ethical and psychological concerns expressed in the fifth/tenth-century Khurasanian Sufi manuals and apologies from the central themes of the Mu'tabirun writings.

Casewit succinctly summarizes the latter's teachings as emphasizing "the theme of parallel worlds (tațābuq/intizām al-adnā wa al-asfal); the principle of correspondence between man, creation, and revelation; the function of the Perfect Man (al-insān al-kāmil) or Universal Servant (al'abd al-kullî) as intermediary between the divine and creation; and God's signs ( $\bar{a} y \bar{a} t$ Allāh) in creation as windows into the otherworld ( $\left.i^{\prime} t i b \bar{a} r\right)$ " (p. 71). The Mu 'tabirun were subsumed under the category of "Sufi" by hagiographers, in particular Ibn al-Zayyat al-Tadili (d. 627/1231) in his highly influential Al-Tashawwuf ilā Rijāl al-Tașawwuf. Thus, two distinct North African and Andalusian trends of mysticism and piety became subsumed under the category of Sufism: "juridical Sufism" on the one hand, represented by figures such as Abu Madyan, and on the other the Mu tabirun, a philosophical-cum-mystical school. 
Having made a convincing case for considering the $\mathrm{Mu}$ tabirun a distinct trend of Islamic mystical thought indigenous to Andalusia and independent of Baghdadi-Khurasanian Sufism, Casewit then turns to looking at one of its most prominent authors: Ibn Barrajan. Chapter 3, "The Life of a Contemplative," provides a rich account of Ibn Barrajan's life and religious orientation. Born around 446/1051, his education included the spectrum of Islamic learning, with an emphasis on Qur' an and Hadith, as well as the "sciences of the ancients" ( 'ulüm al-awa' il). Ibn Barrajan retired from Seville and settled in a nearby village to lead a life of worship and contemplation, training a select group of disciples. His controversial views reached the ear of Sultan 'Ali ibn Yusuf ibn Tashufin, who had him arrested in Cordoba and put on trial in Marrakesh. After he died in prison in 1141, his body was cast on the garbage dump without a ritual washing or a funeral prayer. 'Ali ibn Hirzihim, an important teacher of Abu Madyan, rallied the masses to pray over him, an event that filled Marrakesh's public squares, before burying him.

Chapter 4, "The Works of Ibn Barrajan," provides a detailed summary of Ibn Barrajan's writings, ordered chronologically, with a discussion of the manuscript traditions and a summary of each text's central themes. Casewit notes four key texts. The first, Al-Irshād ilā Subul al-Rashād is lost but was presumably a sizable book, as it focused on the concordance between the Qur' an and the Hadith recorded in Sahịh Muslim (the Andalusians and North Africans favored Muslim over Bukhari). Casewit tracks down citations of Ibn Barrajan's Irshād and notes citations by the Mamluk Badr al-Din al-Zarkashi in his monumental work on Qur'anic studies: AlBurhān fì 'Ulüm al-Qur'ān.

The second work is Ibn Barrajan's commentary on the divine names, Sharh Asmā' Allāh al-Husnā. Casewit provides a judicious summary of Ibn Barrajan's method in expounding on the Divine Names, which Ibn Barrajan details in a fifteen-page introduction to the text. Scholars assume his indebtedness to Ghazali, but Casewit argues that he was, in fact, an original author and was not informed by Ghazali. Significantly, Ibn Barrajan does not advocate a notion of takhalluq bi akhlāq illāh, but rather emphasizes al-takhalluq bi ma 'ānī asmā 'ihi. The third and fourth works are Ibn Barrajan's tafsīrs, the large five-volume Tanbīh al-Afhäm and the Idāh alHikmah bi Ahkām al-'Ibra, which Casewit and Gerhard Böwering edited in a large single-volume: A Qur'añ Commentary by Ibn Barrajañ of Seville (d. 536/1141) (Leiden: Brill, 2016).

The remaining chapters detail key themes in Ibn Barrajan's teachings. Chapter 5 lays out the cosmology and ontology that inform his writings. 
Chapters 6 and 7 demonstrate how that plays out in his tafsìr, while chapter 8 details his key contribution: al-i 'tibār. Chapter 5, "The Divine Descent," analyzes Ibn Barrajan's cosmology and the relation between God and creation. Casewit provides a lucid account of three key cosmological doctrines: "the universal servant" (al- 'abd al-kulli) ), "the reality upon which creation is created" (al-haqq al-makhlüq bihi al-khalq), and Ibn Barrajan's unique conception of "the signs of God" (āyāt Allāh). Underpinning this cosmology is a notion of correspondence among the human being, creation, and revelation. Aspects of Ibn Barrajan's teachings are later developed in different ways by Ibn al- 'Arabi and his school in the East, in particular the notion of "the Perfect Man" (al-insān al-kāmil).

Chapter 6, "The Hermeneutics of Certainty," is dedicated to Ibn Barrajan's Qur'anic hermeneutics. The distinction between the Sufis of the East and the Mu'tabirun, as argued by Casewit throughout the book, is most pronounced here. Ibn Barrajan's two tafsirs are distinct from the Sufi mode of Qur' anic exegesis known as "exegesis by way of allusion" (al-tafsir bi al-ishārah). Rather than atomistically commenting on the Qur' an through correspondences between allusions of verses and the subjective spiritual state of the individual Sufi at a given moment, Ibn Barrajan's method of $i^{\prime}$ tibār presents a contemplative reading built upon a cosmology whose central concept is that of correspondence among the Book, man, creation, and God. His exegesis thus emphasizes Qur'anic coherence (nazm). Given his specialization in Hadith, as well as the notion developed by Shafi ' $i$ of the Hadith being "revelation not recited in prayer" (wahy ghayr matlū), Ibn Barrajan is also keen to note the correspondence between the Qur' an and the Hadith.

Chapter 7, "A Muslim Scholar of the Bible," focuses on a unique aspect of Ibn Barrajan's tafsìrs, namely, its use of the Bible. Ibn Barrajan invokes and cites Biblical passages in his tafsìrs but maintains the principle of "Qur' anic hegemony," which Casewit characterizes as giving the Qur' an epistemological supremacy in assessing the truth of scriptures as well as of Hadith.

The final chapter, "The Human Ascent," is dedicated to Ibn Barrajan's central intellectual and mystical practice that is applied equally to the universe and the book of God: $i$ 'tibār. For him, this practice originates in the Qur'an's repeated admonition to reflect, take heed, and draw counsel. Given Ibn Barrajan's conception of correspondence, the mystic is to contemplate the self, the cosmos, and God's Book and is thereby able to "cross over" from the visible to the unseen. This concept has its roots in the work 
of Ibn Masarra; however, Ibn Barrajan disassociates himself from his predecessor's controversial ideas, in particular seeing $i$ 'tibār as a modality of revelation. Casewit walks the reader through a number of ideas associated with Ibn Barrajan's employment of $i$ 'tibār that draw on cosmological notions, the descent of God's command, the conception of time, and numerology. As part of "crossing over from the visible to the unseen," the mystic is granted insight into future events that are part of the unseen. Ibn Barrajan is remembered for predicting the Muslim recapture of Jerusalem from the Crusaders in $538 \mathrm{AH}$.

As this summary indicates, The Mystics of al-Andalus covers a lot of ground and is a rewarding read. Casewit deftly navigates the secondary literature of a number of areas of Islamic studies, weaving his interventions with a close reading of the works of the $\mathrm{Mu}$ 'tabirun. For scholars of Islamic theology, philosophy, and mysticism, The Mystics of al-Andalus offers a critical intervention into a number of fields. It fills an important lacuna in our knowledge of Andalusian mystical thought and brings to light the teachings of an indigenous Andalusian trend before it was subsumed and somewhat forgotten under the catch-all title of "Sufism." Scholars of Ibn al-'Arabi in particular will find a rich and detailed summary of the intellectual and spiritual milieu from which al-Shaykh al-Akbar emerged a century later. For Qur' anic studies, this book offers an in-depth study of a unique tafsir , explicating Ibn Barrajan's philosophical outlook and method.

Jawad Anwar Qureshi

$\mathrm{PhD}$ Candidate, Islamic Studies University of Chicago Divinity School, Chicago, IL 